11010

US Army Corps

of Engineers

Waterways Experiment

Station

\title{
Use of Population Modeling to Enhance the Gulf Sturgeon Recovery Plan
}

by James P. Kirk, K. Jack Killgore, James V. Morrow, Jr., WES

Howard E. Rogillio, Louisiana Department of Wildlife and Fisheries

Charles Knight, Mississippi Museum of Natural Sciences

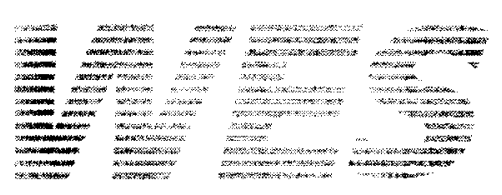

Approved For Public Release; Distribution Is Unlimited

Prepared for Headquarters, U.S. Army Corps of Engineers 
The contents of this report are not to be used for advertising, publication, or promotional purposes. Citation of trade names does not constitute an official endorsement or approval of the use of such commercial products.

The findings of this report are not to be construed as an official Department of the Army position, unless so designated by other authorized documents. 


\section{Use of Population Modeling to Enhance the Gulf Sturgeon Recovery Plan}

by James P. Kirk, K. Jack Killgore, James V. Morrow, Jr.

U.S. Army Corps of Engineers

Waterways Experiment Station

3909 Halls Ferry Road

Vicksburg, MS 39180-6199

Howard E. Rogillio

Louisiana Department of Wildlife and Fisheries

61386 Fish Hatchery Road

LaCombe, LA 70445

Charles Knight

Mississippi Museum of Natural Sciences

111 North Jefferson Street

Jackson, MS 39202

Final report

Approved for public release; distribution is unlimited 


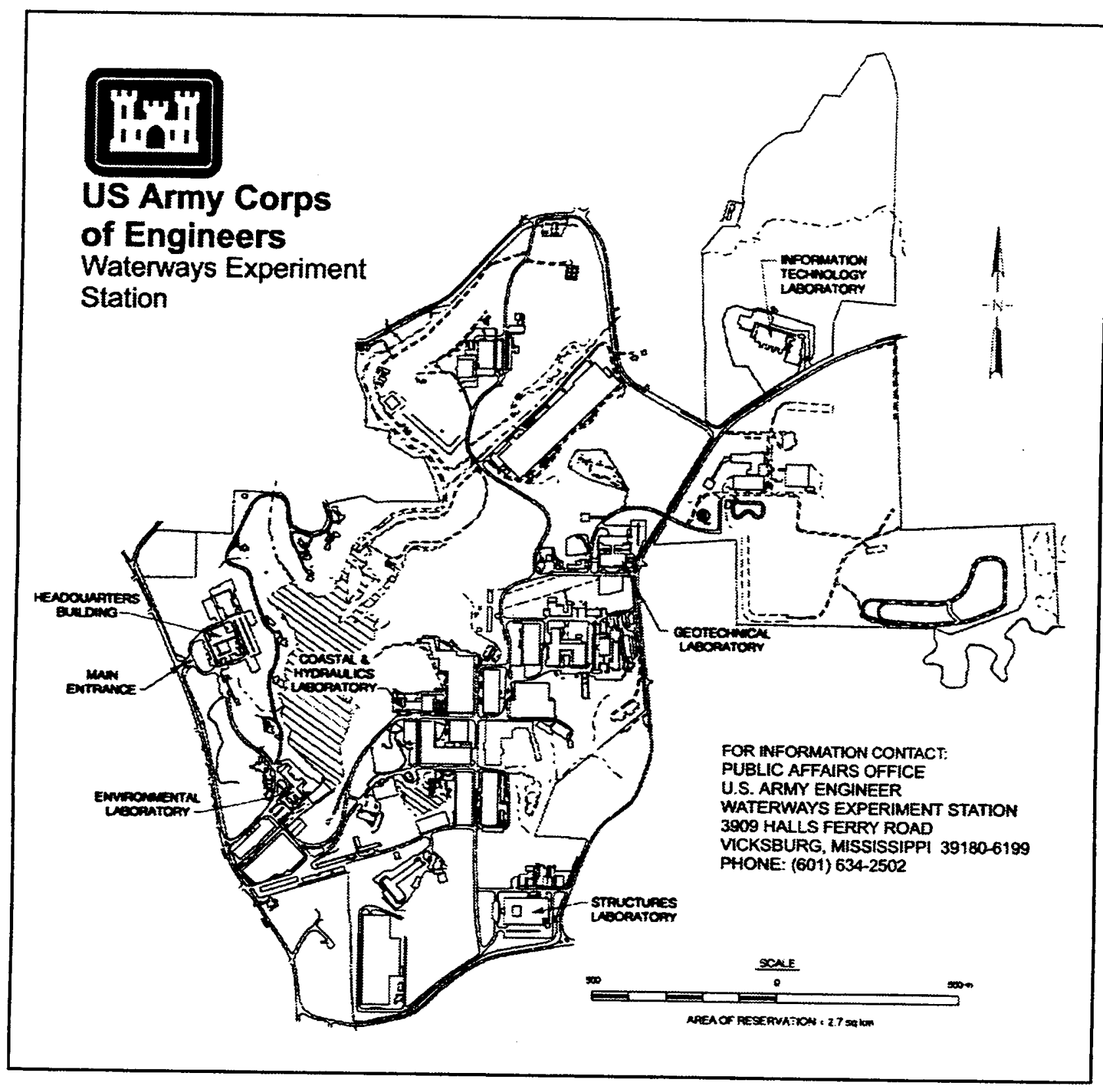

Waterways Experiment Station Cataloging-in-Publication Data

Use of population modeling to enhance the Gulf Sturgeon Recovery Plan / by James P. Kirk [et al.] ; prepared for U.S. Army Corps of Engineers.

32 p. : ill. ; $28 \mathrm{~cm}$. - (Technical report ; EL-98-3)

Includes bibliographical references.

1. Gulf sturgeon - Mortality. 2. Fish populations - Research. 3. Peart River (Miss. and La.) I. Kirk, James Philip, 1948- II. United States. Army. Corps of Engineers. III. U.S. Army Engineer Waterways Experiment Station. IV. Environmental Laboratory (U.S. Army Engineer Waterways Experiment Station) V. Series: Technical report (U.S. Army Engineer Waterways Experiment Station) ; EL-98-3.

TA7 W34 no.EL-98-3 


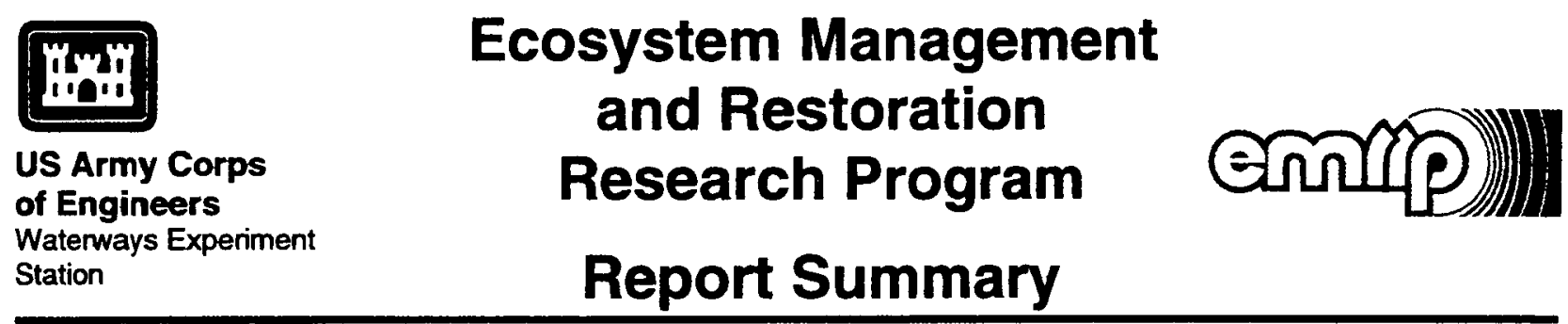

\section{Use of Population Modeling to Enhance the Gulf Sturgeon Recovery Plan (TR EL-98-3)}

ISSUE: A comprehensive strategy for recovery of the Gulf sturgeon, listed as threatened throughout its range in 1991, was published in 1995. The species will be considered for de-listing if, by 2023 , populations are shown to be self-sustaining and efforts are under way to restore lost or degraded habitats.

RESEARCH: Results of monitoring of Gulf sturgeon in the Pearl River are reported, and population models developed from these data are described. Annual trends in population size and structure for different rates of mortality and recruitment are simulated. Finally, enhancements in the Gulf Sturgeon Recovery Plan are illustrated using data presented in this study, and a case is made for using population modeling in developing recovery strategies.

SUMMARY: The Gulf sturgeon population in the Pearl River was monitored from 1992 through 1996 and compared with historical data sets from the 1960s and 1980s. Over the last 30 years, annual mortality rates ranged from 9 percent to almost 40 percent and have been significantly correlated with commercial fishing effort.
Population modeling was used to evaluate the species' status and recovery potential. Population models indicated that catch and effort data specified in the Gulf Sturgeon Recovery Plan may not detect a declining population. The models can be used to simulate annual variation in population size under different rates of mortality. Recovery goals can address specific sources of mortality simulated in the model, and monitoring can determine the success of recovery efforts. Population modeling does not require considerably more effort or expertise over that already required to conduct monitoring studies.

AVAILABILITY: The report is available on Interlibrary Loan Service from the U.S. Army Engineer Waterways Experiment Station (WES) Library, 3909 Halls Ferry Road, Vicksburg, MS 391806199; telephone (601) 634-2355. To purchase a copy, call the National Technical Information Service (NTIS) at (703) 487-4650. For help in identifying a title for sale, call (703) 487-4780. NTIS numbers may also be requested from the WES librarians.

About the Authors: This report was written by Dr. James P. Kirk, Dr. K. Jack Killgore, and Mr. James V. Morrow, Ir. WES Enviroumental Laboratory; Mr. Howard E. Rogillio, Louisiana Department of Wildlife and Fisheries; and Mr. Charles Knight, Mississippi Museum of Natural Scieaces. Point of contact is Dr. Kirk, USAE Waterways Experiment Station, ATIN: CEWES-ER-A, 3909 Halls Ferry Road, Vicksburg, MS 39180-6199, phone: (601) $634-3060$. 


\section{Contents}

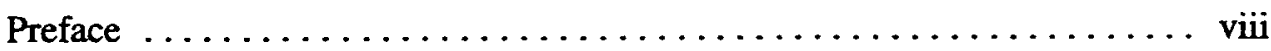

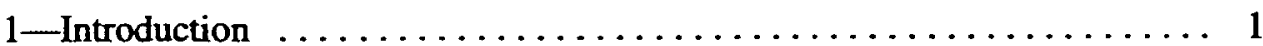

2-Population Attributes of the Gulf of Mexico Sturgeon in the lower Pearl River System, Louisiana-Mississippi ............. 3

Methods ............................ 3

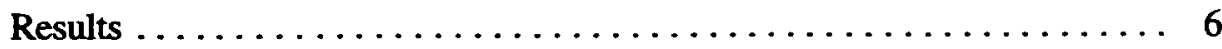

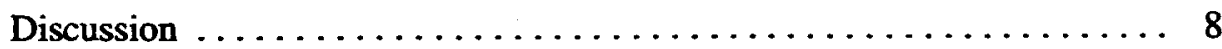

3-Recommended Enhancements to the Gulf Sturgeon Recovery Plan .... . 11

Methods ............................. 11

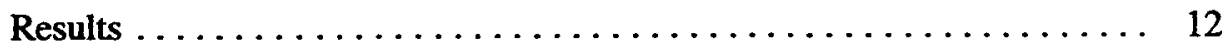

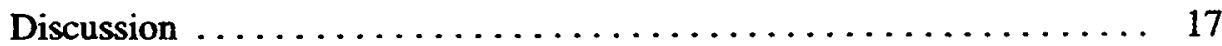

Enhancements to the Gulf Sturgeon Recovery Plan Using

Population Modeling $\ldots \ldots \ldots \ldots \ldots \ldots \ldots \ldots \ldots \ldots \ldots$

4 Conclusions and Recommendations $\ldots \ldots \ldots \ldots \ldots \ldots \ldots \ldots \ldots$

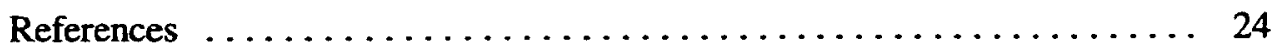

SF 298

\section{List of Figures}

Figure 1. The Pearl River and Lake Pontchartrain system, Louisiana-Mississippi .................. 4

Figure 2. The number of commercial gill netting and shrimping licenses sold in three parishes (Orleans, St. Bernard, and St. Tammany) surrounding Lake Pontchartrain between 1966 and 1995 and the corresponding annual survival rate estimated for Gulf sturgeon . . . . . . . 9 
Figure 3. Future population sizes of Gulf sturgeon, starting with the current age structure and population, over the 27-year period of the Gulf Sturgeon Recovery Plan modeled with annual mortality rates of 9,26 , and 40 percent and constant yearly recruitment of 80 age- 1 fish $\ldots \ldots \ldots \ldots \ldots \ldots \ldots \ldots . \ldots \ldots$

Figure 4. Future proportion of adult stock (PAS) of Gulf sturgeon, starting with the current age structure and population, over the 27-year period of the Gulf Sturgeon Recovery Plan modeled with annual mortality rates of 9,26 , and 40 percent and constant recruitment of 80 age-1 fish . . . . . . . . . 14

Figure 5. Future population sizes of Gulf sturgeon, starting with the current age structure and population, over the 27-year period of the Gulf Sturgeon Recovery Plan modeled with annual mortality rates of 9,26 , and 40 percent and normally distributed recruitment with a mean of 80 age- 1 fish and a standard deviation of $40 \ldots \ldots \ldots \ldots \ldots \ldots \ldots \ldots$

Figure 6. Future proportion of adult stock of Gulf sturgeon, starting with the current age structure and population, over the 27-year period of the Gulf Sturgeon Recovery Plan modeled with annual mortality rates of 9,26 , and 40 percent and normally distributed recruitment with a mean of 80 age-1 fish and a standard deviation of $\mathbf{4 0}$

Figure 7. The numbers of age-1 Gulf sturgeon recruits needed to produce one adult at differing levels of annual mortality $\ldots \ldots 18$

Figure 8. Response of the Pearl River Gulf sturgeon population to varying levels of annual mortality over the period

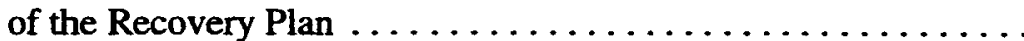

Figure 9. Changes in size structure of the Pearl River Gulf sturgeon population at different levels of mortality over the period of the Recovery Plan $\ldots \ldots \ldots \ldots \ldots \ldots \ldots 21$

\section{List of Tables}

Table 1. Equations and Parameters Used to Estimate Mortality Rate and Population Size of Gulf Sturgeon Populations in the Lower Pearl River System . . . . . . . . . . . . . . .

Table 2. Mean Fork Lengths, Numbers Captured, and Estimated Mortality Rates for Gulf Sturgeon Sampled by Gill

Netting Between 1967 and 1996 in the Pearl River System . . . . . 7 
Table 3. Age and Mean Length at Age of 66 Gulf Sturgeon Captured in the Lower Pearl River System During the Summers of 1995 and 1996

Table 4. Mean Catch Per Unit Effort (CPUE) of Gulf Sturgeon

Populations in the Lower Pearl River, Mississippi-

Louisiana Between 1992 and 1996 


\section{Preface}

The work described in this report was authorized by the Headquarters, U.S. Army Corps of Engineers (HQUSACE), as part of the Ecosystem Management and Restoration Research Program (EMRRP), Work Unit 32982, "Protection and Management of Sturgeon." Program Monitors were Ms. Beverley Getzen, Mr. Pete Juhle, and Ms. Denise White, HQUSACE.

Mr. Dave Mathis (CERD-C) was the EMRRP Coordinator at the Directorate of Research and Development, HQUSACE. Dr. Russell F. Theriot, Environmental Laboratory (EL), U.S. Army Engineer Waterways Experiment Station (WES), was the EMRRP Manager, and Mr. Robert L. Lazor was Assistant Manager.

This report was prepared by Dr. James P. Kirk, Dr. K. Jack Killgore, and Mr. James V. Morrow, Jr., Aquatic Ecology Branch (AEB), Ecological Research Division (ERD), EL, WES; Mr. Howard E. Rogillio, Louisiana Department of Wildlife and Fisheries, LaCombe, LA; and Mr. Charles Knight, Mississippi Museum of Natural Sciences, Jackson, MS.

The study was performed under the supervision of Dr. Edwin A. Theriot, Chief, AEB; and Dr. Alfred F. Cofrancesco, Acting Chief, AEB; Dr. Conrad J. Kirby, Chief, ERD; and Dr. John Harrison, Director, EL.

At the time of publication of this report, Director of WES was Dr. Robert W. Whalin. Commander was COL Robin R. Cababa, EN.

The report should be cited as follows:

Kirk, J. P., Killgore, K. J., Morrow. J. V., Jr., Rogillio, H. E., and Knight, C. (1998). "Use of population modeling to enhance the gulf sturgeon recovery plan," Technical Report EL-98-3, U. S. Army Engineer Waterways Experiment Station, Vicksburg, MS.

The contents of this report are not to be used for advertising, publication, or promotional purposes. Citation of trade names does not constiute an official endorsement or approval of the use of such commercial products. 


\section{Introduction}

The Gulf of Mexico sturgeon Acipenser oxyrinchus desotoi is a subspecies of the Atlantic sturgeon (Vladykov 1955) that historically ranged from Tampa Bay to the Mississippi River and possibly farther west (Lee et al. 1980). This diadromous fish, which is refered to as the Gulf sturgeon, spends cool months (October or November through March or April) in estuarine or marine habitats and the balance of the year in freshwater rivers (Odenkirk 1989, Foster 1993, Clugston, Foster, and Carr 1995). Adults and juveniles participate in the yearly migration (Carr 1983, Foster 1993). All growth occurs in estuarine and marine habitats (Clugston, Foster, and Carr 1995) and spawning occurs during early spring in freshwater rivers (Wooley, Moon, and Crateau 1982). Other than spawning, reasons for utilizing freshwater habitats are unknown (Foster 1993). Eggs have been collected in the Suwannee River (Marchant and Shutters 1996) and the Choctawhatchee River ${ }^{1}$, and larvae have been collected in the Apalachicola River (Wooley, Moon, and Crateau 1982). Otherwise, little is known of reproductive behavior and habitat requirements of early life history stages.

The Gulf sturgeon was listed as threatened throughout its range in 1991 (U. S. Fish and Wildlife Service 1991). Declines are attributed to overexploitation (Barkuloo 1988), blockage of migration routes, and deterioration of water quality (Wooley and Crateau 1985, U. S. Fish and Wildlife Service and Gulf States Marine Fisheries Commission 1995). Gulf sturgeon will be considered for removal from Federal listing if, by 2023, populations are shown to be self-sustaining and efforts are underway to restore lost or degraded habitats (U. S. Fish and Wildlife Service and Gulf States Marine Fisheries Commission 1995). Recovery will vary greatly between systems, prompting the need for sitespecific recovery plans.

Recovery plans are developed by interagency teams familiar with the listed species. The plan provides specific goals to prevent further reductions in numbers, and if successful, to de-list the species. Recent advances in monitoring and population modeling have provided new analytical tools that can be incorporated in recovery plans to evaluate population trends for different management options.

\footnotetext{
' Personal communication, from F. Parauka, U.S. Fish and Wildlife Service.
} 
This report demonstrates that the standard approaches of monitoring sturgeon can be expanded to include population models in order to recommend enhancements to recovery plans. Three steps were followed during the course of this study:

1. Monitoring results of Gulf sturgeon in the Pearl River were described, and population models were developed from these data.

2. Annual trends in population size and structure for different rates of mortality and recruitment were simulated to demonstrate the importance of quantifying such rates for monitoring and managing the recovery of long-lived species such as sturgeon.

3. Enhancements in the Gulf Sturgeon Recovery Plan were illustrated using data presented in this study, and a case was made for using population modeling in developing recovery strategies. 


\section{Population Attributes of the Gulf of Mexico Sturgeon in the Pearl River System, Louisiana-Mississippi}

This chapter estimates mortality and population size of Gulf sturgeon in the Pearl River system and discusses possible causes of mortality. The Pearl River drains 22,688 $\mathrm{km}^{2}$ in central Mississippi and southeastern Louisiana (U. S. Army Engineer District, Mobile 1970), flows into Lake Borgne and the Rigolets, and is part of the Lake Pontchartrain estuary (Figure 1). Potential barriers to upstream fish migration include the Ross Barnett Dam, the Pools Bluff sill, and the Bogue Chitto sill. The Ross Bamett Dam was constructed at river mile 301 in 1964 and is a total barrier to upstream fish migration. The Pools Bluff sill (river mile 48.5) on the Pearl River and the Bogue Chitto sill (river mile 3.9) on the Bogue Chitto River, were constructed in 1956 and are barriers to upstream fish migration during low water (U. S. Fish and Wildlife Service and Gulf States Marine Fisheries Commission 1995). No Gulf sturgeon have been captured upstream from Ross Barnett Dam since its construction; however, some are occasionally captured upstream from the Pools Bluff sill ' (Miranda and Jackson 1987). The majority of Gulf sturgeon in the Pearl River system inhabit reaches downstream from the two sills (Morrow et al., in press).

\section{Methods}

Gulf sturgeon were captured with bottom-set gill nets. Both experimental and single mesh gill nets were used. Experimental gill nets were $27.5 \mathrm{~m}$ long and $1.83 \mathrm{~m}$ deep with mesh sizes of $3.81,7.62,12.7,15.2$, and $17.8 \mathrm{~cm}$ stretch. Single mesh gill nets were $1.83 \mathrm{~m}$ deep and 30.5 to $91.5 \mathrm{~m}$ long, depending on the size of the water body being fished. Mesh size of single mesh gill nets varied; stretch meshes of $14.0,15.2,17.8,19.1,20.3,22.8$, and $30.4 \mathrm{~cm}$ were used. Nets were positioned across the primary channel at low flows and parallel to currents

\footnotetext{
${ }^{1}$ Mississippi Museum of Natural Sciences, specimen catalogue numbers 15,589 and 20,206.
} 


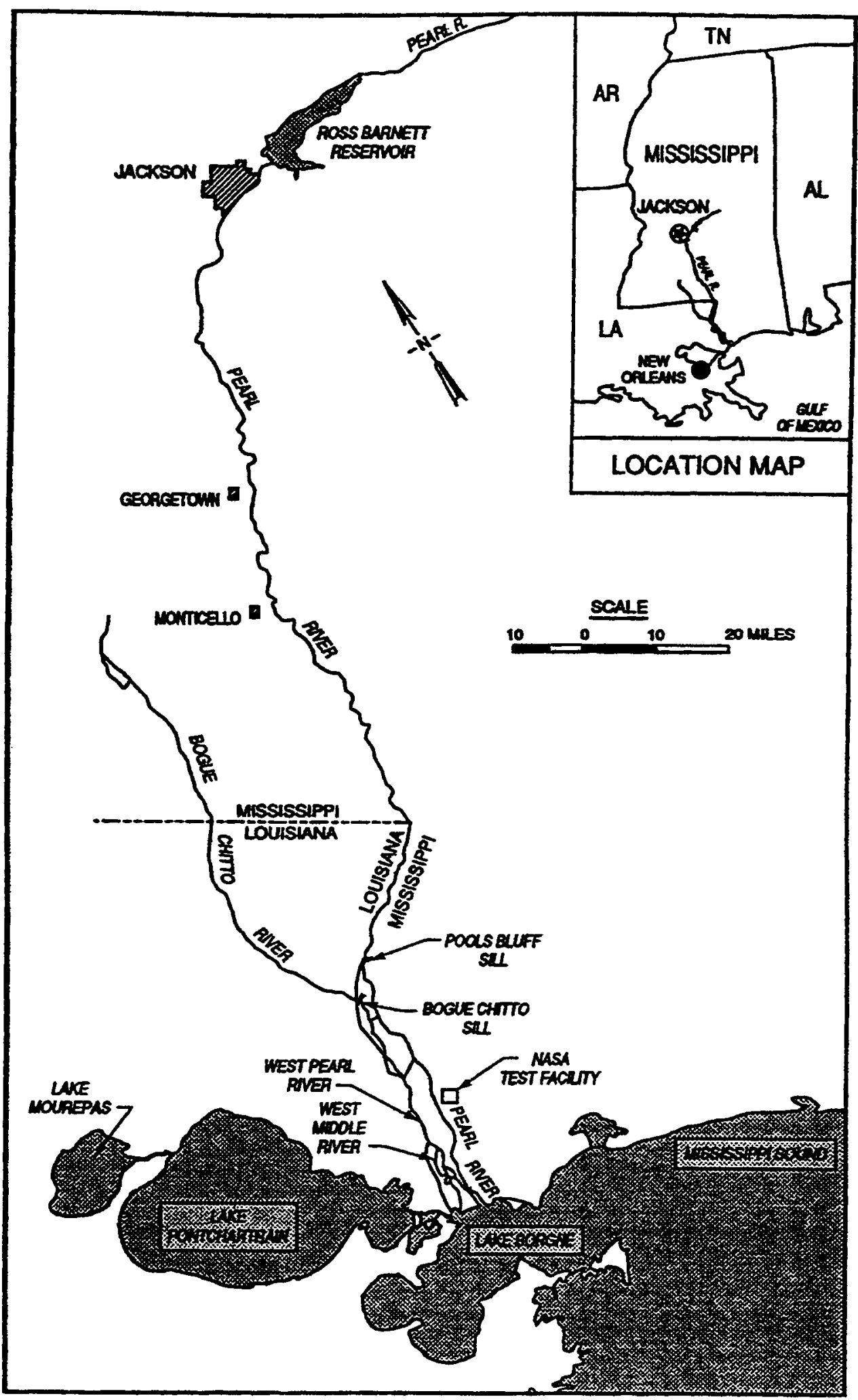

Figure 1. The Pearl River and Lake Pontchartrain system, LouisianaMississippi 
or in eddies and backwater areas at medium to high flows. The Pearl River system downstream from the Pools Bluff and Bogue Chitto sills was sampled from 1992 through 1996 for a total of 256,930 net-meter hours. The Pearl River between Pools Bluff sill and Ross Barnett Dam was sampled for a total of 131,530 net-meter hours in 1995 and 1996. Netted Gulf sturgeon were measured for total length (TL) and fork length (FL) to the nearest $\mathrm{cm}$, weighed to the nearest $30 \mathrm{~g}$, and tagged with passive integrated transponder (PIT) tags and either Peterson disk tags or Floy tags. Sections of the anterior pectoral fin ray were removed from 35 and 36 Gulf sturgeon in 1995 and 1996 and examined to determine age (Rien and Beamesderfer 1994).

Two historical data sets from the Pearl River system were also used in this analysis. Weights of 64 Gulf sturgeon captured in the lower Pearl River system from 1967-1969 (Davis et al. 1970) were converted to fork length using a weightlength relation (Morrow et al., in press). These sturgeon were captured in trammel nets that were $183 \mathrm{~m}$ long with $2.54-\mathrm{cm}$ square mesh. The second data set consisted of total lengths of 61 Gulf sturgeon captured in the lower Pearl River by F. Pezold of Northeast Louisiana University in 1985 using 91.5-m experimental mesh (3.81-, 7.62- and 15.2-cm stretch) gill nets (unpublished data). Fork length was estimated using a relation determined by Morrow et al. (in press).

The total instantaneous rate of mortality $Z$ (Ricker 1975) was estimated from length at capture data for 1967-1969, 1985, and 1992-1996 using Equation 1 in Table 1 (Gulland 1983). Too few adults were captured to develop von Bertalanffy growth equation parameters (theoretical asympotic forks length $L^{\infty}$, growth coefficient in years ${ }^{-1} k$, and theoretical age at which fork length is 0 $t_{0}$ ); therefore, this study relied on fish captured by Huff (1975) to compute this equation. Because of inherent limitations in this method and to provide a comparison, $Z$ was also estimated with a catch curve (Ricker 1975) for 66 Gulf sturgeon captured in 1995 and 1996.

Population size was estimated using the Schnabel method (Schnabel 1938; Everhart, Eipper, and Youngs 1975) (Table 1). Each sampling day in which Gulf sturgeon were captured was counted as one sample and recaptures within the day were disregarded. Summertime populations were estimated two ways. First, size of all known Gulf sturgeon concentrations were estimated where each concentration was treated as an isolated population with no mixing among them. Total population size was the sum of all concentrations. Secondly, complete mixing and estimated population of Gulf sturgeon was assumed for the entire Pearl River system downstream from the Bogue Chitto and Pools Bluff sills. Because no Gulf sturgeon concentrations have been documented upstream from the sills, the population downstream from the sills was assumed to approximate the summer Pearl River population.

Commercial fishing license data from 1960 to 1995 was obtained from the Louisiana Department of Wildlife and Fisheries (LDWF). Numbers of commercial licenses sold were used as indices of commercial fishing effort. These numbers were plotted over time and compared to Gulf sturgeon mortality rates calculated in this study. 


\begin{tabular}{|c|c|}
\hline \multicolumn{2}{|c|}{$\begin{array}{l}\text { Table } 1 \\
\text { Equations and Parameters Used to Estimate Mortality Rate and Population Size of Gulf } \\
\text { Sturgeon Populations in the Lower Pearl River System }\end{array}$} \\
\hline Parameter & Definition \\
\hline \multicolumn{2}{|c|}{ Equation 1} \\
\hline$Z=k\left(L_{\infty}-[) /\left[-L_{c}\right.\right.$ & Mortality estimated from mean length at capture data \\
\hline$z$ & Instantaneous rate of total mortality \\
\hline$k$ & Growth constant from von Bertananffy equation (0.1012) \\
\hline$L_{\infty}$ & $\begin{array}{l}\text { Theoretical maximum fork length from von Bertananffy growth } \\
\text { equation }(196.5 \mathrm{~cm})\end{array}$ \\
\hline [ & Mean fork length captured by netting \\
\hline L. & Minimum fork length vulverable to capture \\
\hline \multicolumn{2}{|c|}{ Equation 2} \\
\hline$N=\left(C_{1} \times M_{1}\right)+\left(C_{2} \times M_{2}\right)+\ldots\left(C_{1} \times M_{1}\right) / R_{1}+R_{2}+\ldots R_{1}$ & Schnabel method for estimating population \\
\hline $\mathbf{N}$ & Estimated population size \\
\hline c & Total number of animals captured per sample \\
\hline M & Number of tagged animals at large when sample was taken \\
\hline$R$ & Number of tagged animals captured in the sample \\
\hline
\end{tabular}

River stage data for the Bogue Chitto River at Bush, Louisiana (approximately $5 \mathrm{~km}$ upstream from the sill) were obtained from the U. S. Geological Survey for October 1991 through September 1996. The maximum stage when Gulf sturgeon were captured at the sill was deemed the minimum level for which upstream migration was possible. Mean daily stage data were compared to this minimum level to estimate amount of time the Bogue Chitto sill was a barrier to upstream Gulf sturgeon migration.

\section{Results}

Two hundred fifty-seven Gulf sturgeon were captured in four reaches of the Pearl River system from 1992 through 1996. No Gulf sturgeon were netted upstream from the sills in this study; however, one was captured by a commercial fisherman near Monticello, Mississippi during April 1996 (Knight, in press). The mean fork length (FL) for this period was $74 \mathrm{~cm}$, standard deviation (SD) $=22$, range $32-152 \mathrm{~cm}$. Mean fork length by year ranged from $65 \mathrm{~cm}$ in 1992 to 85 $\mathrm{cm}$ in 1993 (Table 2). Proportion of adult stock (PAS) (i.e., FL > $130 \mathrm{~cm}$ ) ranged from 2.9 percent in 1996 to 0.0 percent in 1992, 1993, and 1995 with a mean of 1.6 percent. Growth parameters $k$ and $L_{\infty}$, calculated from Huff (1975), were 0.1012 and $196.5 \mathrm{~cm}$ FL respectively, and $L_{c}$ from 1992 to 1996 was $32 \mathrm{~cm}$ FL. Instantaneous rate of total mortality $Z$, estimated from mean fork length at 


\begin{tabular}{|c|c|c|c|c|c|}
\hline \multicolumn{6}{|c|}{$\begin{array}{l}\text { Table } 2 \\
\text { Mean Fork Lengths, Numbers Captured, and Estimated Mortality Rates for Gulf } \\
\text { Sturgeon Sampled by Gill Netting Between } 1967 \text { and } 1996 \text { in the Pearl River System }\end{array}$} \\
\hline \multirow[b]{3}{*}{ Year } & \multirow[b]{3}{*}{ Mean FL } & \multirow[b]{3}{*}{$\mathbf{N}$} & \multirow[b]{3}{*}{ SD } & \multicolumn{2}{|c|}{ Total mortality } \\
\hline & & & & Instantaneous (Z) & Annual (A, \%) \\
\hline & & & & Mean & Mean \\
\hline $1966-1969^{\prime}$ & 1,119 & 64 & - & 0.09 & 9 \\
\hline $1985^{2}$ & 547 & 60 & 131 & 0.50 & 40 \\
\hline 1992 & 652 & 16 & 219 & 0.40 & 33 \\
\hline 1993 & 847 & 28 & 204 & 0.21 & 29 \\
\hline 1994 & 776 & 54 & 199 & 0.26 & 23 \\
\hline 1995 & 661 & 57 & 199 & 0.38 & 32 \\
\hline 1196 & 743 & 102 & 288 & 0.29 & 25 \\
\hline $1992-1996$ & 737 & 257 & 219 & 0.30 & 26 \\
\hline
\end{tabular}

capture, ranged from 0.21 in 1993 to 0.40 in 1992 with mean of 0.30 for 1992 1996. These convert to annual mortality rates of 23 percent to 33 percent with mean of 26 percent (Table 2). Age of 66 Gulf sturgeon captured in 1995 and 1996 ranged from 1 to 11 years (Table 3). Total instantaneous mortality, estimated with a catch curve using these fish, was 0.271 (file of regression $r^{2}=$ 0.61 ) which converts to an annual mortality rate of 24 percent.

Mean fork lengths of Gulf sturgeon captured in 1967-1969 (Davis et al. 1970) and 1985 (Pezold, unpublished) were $112 \mathrm{~cm}$ and $55 \mathrm{~cm}$, respectively. From these lengths $Z$ was calculated to be 0.09 and 0.50 , respectively, which convert to annual mortality rates of 9 and 39 percent (Table 2).

Three summertime concentrations of Gulf sturgeon were located in the Pearl River system: West Middle River reach, Pearl River at NASA, and Bogue Chitto River at the Bogue Chitto sill (Figure 1). Summertime population estimates were 138,85 , and 10 , respectively for a total of 233 . Estimated population size was 292 when population mix was assumed throughout the system.

After peaking in 1987, numbers of licenses sold for commercial shrimping and gill netting from the parishes surrounding Lake Pontchartrain declined steadily until 1995, when numbers were 40 percent of those in 1987. The trend for the three parishes of the Pearl River estuary were similar to the statewide trend. Number of licenses sold annually and annual survival rate of Gulf sturgeon appeared to be correlated $\left(r^{2}=0.80 ; F=16.1 ; P>F=0.02\right)$ (Figure 2). 


\begin{tabular}{|c|c|c|c|}
\hline \multicolumn{4}{|c|}{$\begin{array}{l}\text { Table } 3 \\
\text { Age and Mean Length at Age of } 66 \text { Gulf Sturgeon Captured in the } \\
\text { Lower Pearl River System During the Summers of } 1995 \text { and } 1996\end{array}$} \\
\hline Age (years) & Length $(\mathrm{cm})$ & Number & Length $(\mathrm{cm})_{1}$ \\
\hline 1 & 37 & 3 & 37 \\
\hline 2 & 44 & 18 & 53 \\
\hline 3 & 53 & 17 & 66 \\
\hline 4 & 79 & 13 & 77 \\
\hline 5 & 89 & 7 & 86 \\
\hline 6 & 94 & 3 & 95 \\
\hline 7 & 104 & 2 & 103 \\
\hline 8 & 104 & 1 & 111 \\
\hline 9 & 97 & 1 & 118 \\
\hline 11 & 114 & 1 & 131 \\
\hline
\end{tabular}

Gulf sturgeon were captured at the base of the Bogue Chitto sill on 19 May 1992, 22 July 1992, 8 June 1994, 9 June 1994, 22 May 1996, 8 July 1996, 30 July 1996, 3 September 1996, and 24 September 1996. On all of these dates it was apparent that the sill was a blockage to upstream migration. River stage at Bush ranged from 1.01 to $1.69 \mathrm{~m}$ when Gulf sturgeon were captured at the sill. From October 1991 through September 1996 river stage at Bush was below $1.69 \mathrm{~m} 64$ percent of the time (range $55-80$ percent). Thus, the Bogue Chitto sill may be a blockage to upstream fish migration for 201 to 292 days each year.

\section{Discussion}

Gulf sturgeon for this study were captured using similar methods, gears, and in the same general location as the researchers who compiled the two historic data sets. Consequently, it is possible that these three data sets represent the same sturgeon population sampled at different times. Davis et al. (1970) captured one individual $1.89 \mathrm{~m}$ long, and a $2.05 \mathrm{~m}$ individual was captured during this study, indicating that the $L \infty$ of $1.96 \mathrm{~m}$ used in this study was plausible. Likewise, growth through age 7 was similar to that reported by Huff (1975) indicating that a $k$ of 0.1012 was reasonable. The Gulf sturgeon is a longlived species which attains sexual maturity at a relatively old age. Such species are extremely vulnerable to high mortality rates from habitat loss or exploitation. Even when high mortality rates are reduced, Gulf sturgeon populations may take years to recover. In the Pearl River, mortality was relatively low in 1967-1969 but substantially increased resulting in a rapid population decline. Since 1985, 


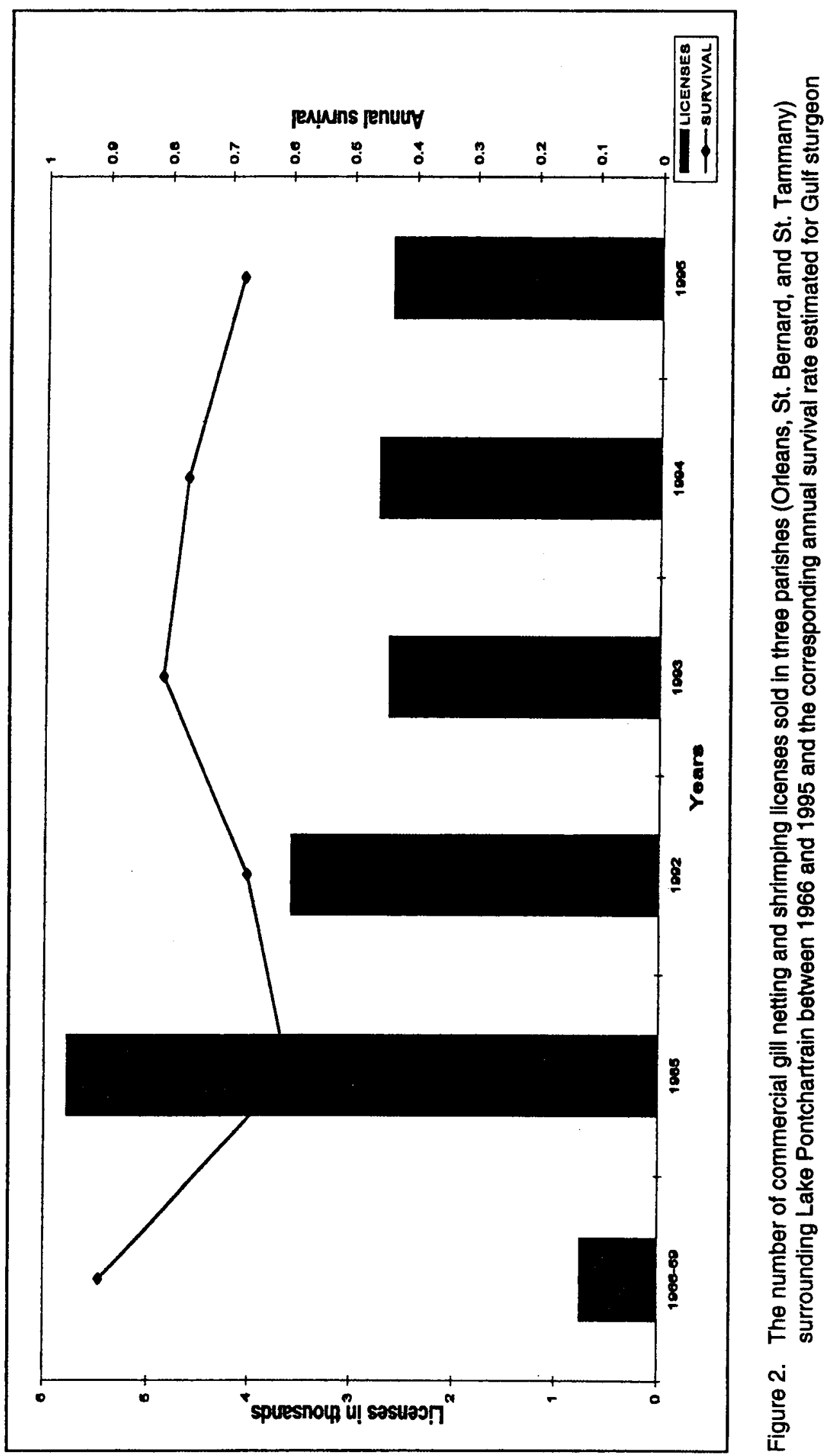

Chapter 2 Population Attributes of the Gulf of Mexico Surgeon in the Pearl River System 
mortality rates may have decreased, but the low numbers of adults indicate that this population could be extirpated if mortality is not substantially reduced.

The first step in reducing mortality was taken in 1990 when fishing for this species was prohibited. However, the mortality rate of Gulf sturgeon and Atlantic sturgeon (Acipenser oxyrinchus oxyrinchus) may be affected by incidental catch in the commercial fishery (Collins, Rogers, and Smith 1996). In 1967-1969 there were less than 1,000 commercial fishing licenses in the three parishes bordering the Pearl River/Lake Pontchartrain estuary, and the annual mortality rate of Gulf sturgeon was 9 percent (Figure 2). By 1985, the number of commercial licenses had increased to about 6,000 and annual mortality rate to 39 percent. The number of commercial licenses peaked in 1987 and declined to 2,800 in the 1990 s when the annual mortality rate was 26 percent. This suggests there was a relationship between commercial fishing effort and Gulf sturgeon mortality.

Anthropogenic impacts in the Pearl River/Lake Pontchartrain system may have affected mortality rates of Gulf sturgeon. These include construction of one mainstem dam and two low head weirs, dredging in the Pearl River and tributaries of Lake Pontchartrain, and the eutrophication of Lake Pontchartrain and its tributaries (Stone et al. 1980). The oldest data set examined in this study was compiled in the late $1960 \mathrm{~s}$ after dam construction and dredging. However, further studies are required to determine spawning locations and migration patterns of this species before other sources of mortality are estimated.

One criterion for de-listing Gulf sturgeon is restoration of lost and degraded habitat (U.S. Fish and Wildlife Service and Gulf States Marine Fisheries Commission 1995). Sturgeon habitat should be defined in terms of system-wide rather than site-specific conditions (Beamesderfer and Farr 1997). Efforts are underway to improve water quality of the Lake Pontchartrain basin which is an important winter habitat for Gulf sturgeon. Potential blockages to Gulf sturgeon migration in this system have not been evaluated to determine if migration is impeded. The preliminary information suggests that the Bogue Chitto sill is a barrier for more than 200 days a year. The Bogue Chitto and Pools Bluff sills should be further studied to determine if fish passage facilities would improve habitat availability. 


\section{Recommended Enhancements to the Gulf Sturgeon Recovery Plan}

The Gulf Sturgeon Recovery/Management Plan, published in 1995, outlined a comprehensive strategy for recovery by 2023 (U. S. Fish and Wildlife Service and Gulf States Marine Fisheries Commission 1995). The short-term objective was to prevent further reduction in the populations, and the long-term objective was to increase numbers to potentially exploitable levels after 2023. The goal or criterion established for the short-term objective was no decline in fishery independent catch per unit effort (CPUE) over a 3 to 5 year period. For the longterm objective, the average rate of recruitment over a 12-year period must equal the average rate of mortality, after which, the goal was to establish populations that can sustain potential exploitation. The Recovery Plan also addressed other issues including incidental by-catch.

In the previous chapter, it was concluded that a population of approximately 300 individuals, dominated by juveniles, inhabited the lower reaches of the system. Due to excessive rates of mortality and few adults, this population was considered precariously close to extirpation. In this chapter, Pearl River data is used to simulate population dynamics and advocate several enhancements to the Recovery Plan. This study is not critical of the Recovery Plan and considers the plan to be competent and comprehensive. However, changes in methodology will improve the ability to monitor and manage Gulf sturgeon populations.

Recommended enhancements to the Recovery Plan address short-term and longterm objectives, do not require greatly expanded funding or effort, and will define an acceptable recovery trajectory (Powers 1996) in terms of population size and age structure.

\section{Methods}

Population trends and age structure were modeled through the year 2023 (target year of the Gulf Sturgeon Recovery Plan) with MOCPOP 2.0 modeling software (Beamesderfer 1991) using annual mortality rates estimated from data collected in this study and from the two historic data sets discussed in Chapter 2. 
Estimated age structure and population size of the summer 1996 Pearl River Gulf sturgeon population was used as the starting point in all modeling. Any individual greater than $130 \mathrm{~cm}$ FL was considered to be an adult capable of reproduction, and thus the proportion of adult stock (PAS) was the number of individuals greater than $130 \mathrm{~cm}$ FL expressed as a percentage of the population. A stock-recruitment function could not be derived with available data, so three different recruitment scenarios, all based on frequency of age- 1 fish, were modeled. The first scenario assumed constant yearly recruitment of 80 age-1 fish; the second assumed yearly recruitment to be normally distributed with mean of 80 and standard deviation of 40 ; the third scenario assumed 10 recruits for each spawning age individual (age $\geq 14$ years). Also calculated was the number of recruits per spawning age individual necessary for a self-sustaining population over the range of mortalities observed.

Recovery trajectories are described (Powers 1996) that would result in a relatively resilient, self-sustaining population by 2023 for each recruitment scenario. Mortality rates that would result in these recovery trajectories were calculated; recovery benchmarks, i.e., PAS and population size, were defined.

\section{Results}

At an annual mortality rate of 9 percent, calculated from Davis et al. (1970) and assuming constant recruitment of 80 fish per year (first scenario), the population increased to 850 in 27 years (Figure 3). Proportion of adult stock increased rapidly and leveled off at 42 percent at year 23 (Figure 4 ). The second scenario, annual recruitment with mean of 80 and SD of 40 , produced populations similar to the first scenario (Figures 5 and 6). The third scenario, recruitment of 10 age-1 fish for each spawning-aged adult, resulted in an expanding population that doubled in size and recruitment in 5 years and continued to expand; however, PAS leveled off at 8 to 9 percent.

At 26 percent annual mortality, the mean observed from 1992 to 1996, the population declined to 270 and PAS leveled off at 4 percent, in 10 and 15 years respectively, under the first scenario (Figures 3 and 4). The second scenario gave results similar to the first except with larger fluctuations (Figures 5 and 6). The third scenario resulted in a population declining toward extirpation with a 50 percent reduction in number and recruitment in the first 11 years and a PAS that stabilized at 7 percent.

The 40 percent annual mortality rate, calculated from the 1985 data set, resulted in a population that declined and leveled off at 200 individuals by year 10 and a PAS that leveled off at 4 percent by year 15 under the first scenario (Figures 3 and 4). Trends were similar under the second scenario, except variance in population size resulted in possible extirpation points (Figure 5 and 6). Under the third scenario, the population rapidly approached extirpation, with numbers and recruitment declining by 50 percent in five years and PAS stabilizing at 7 percent. 


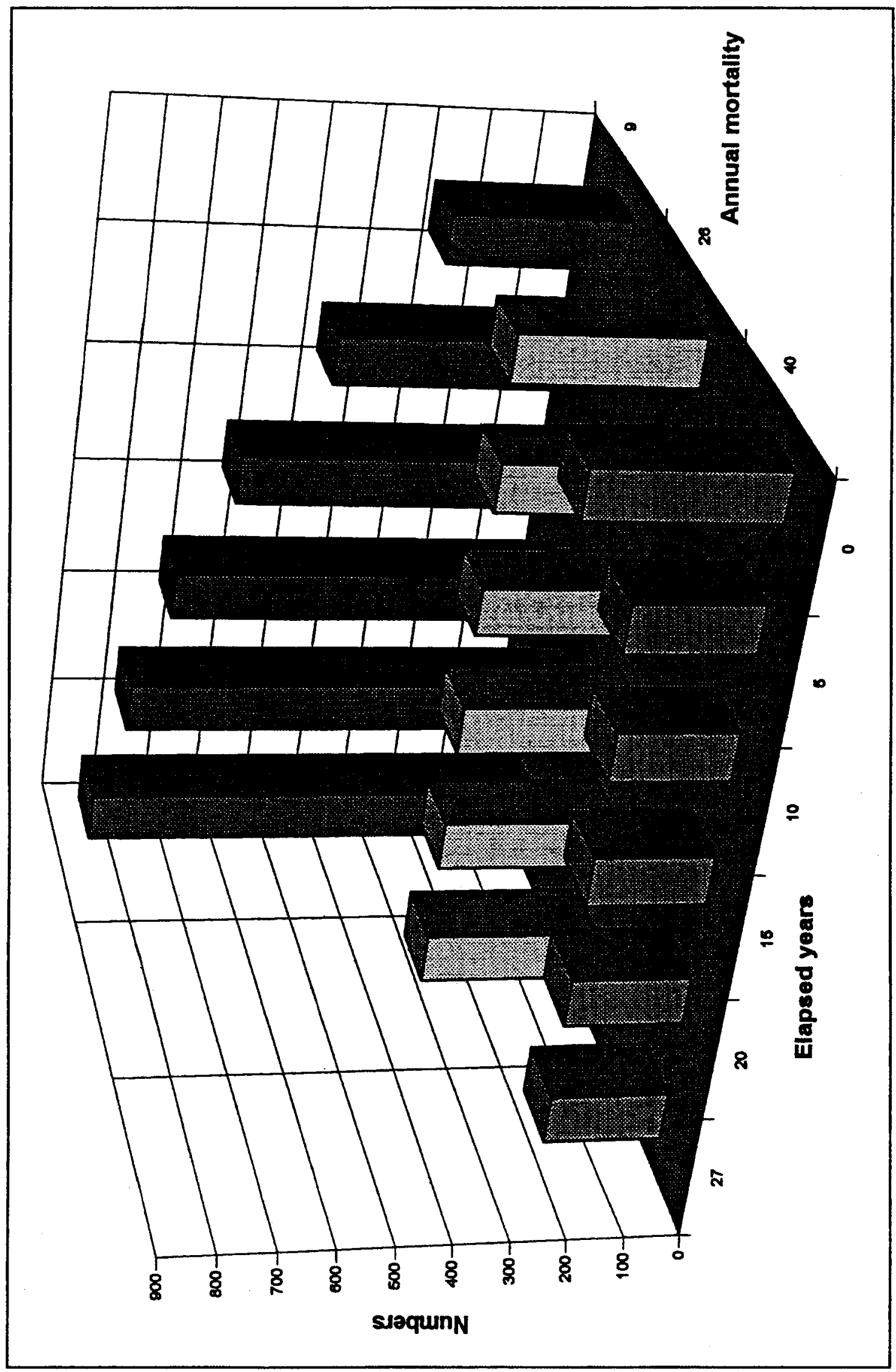

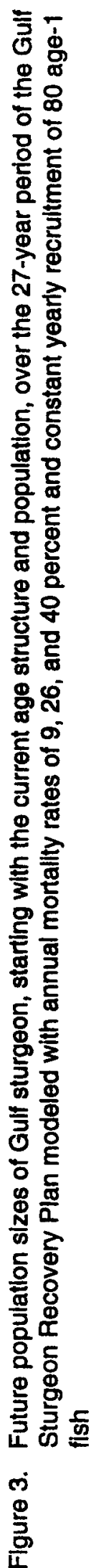




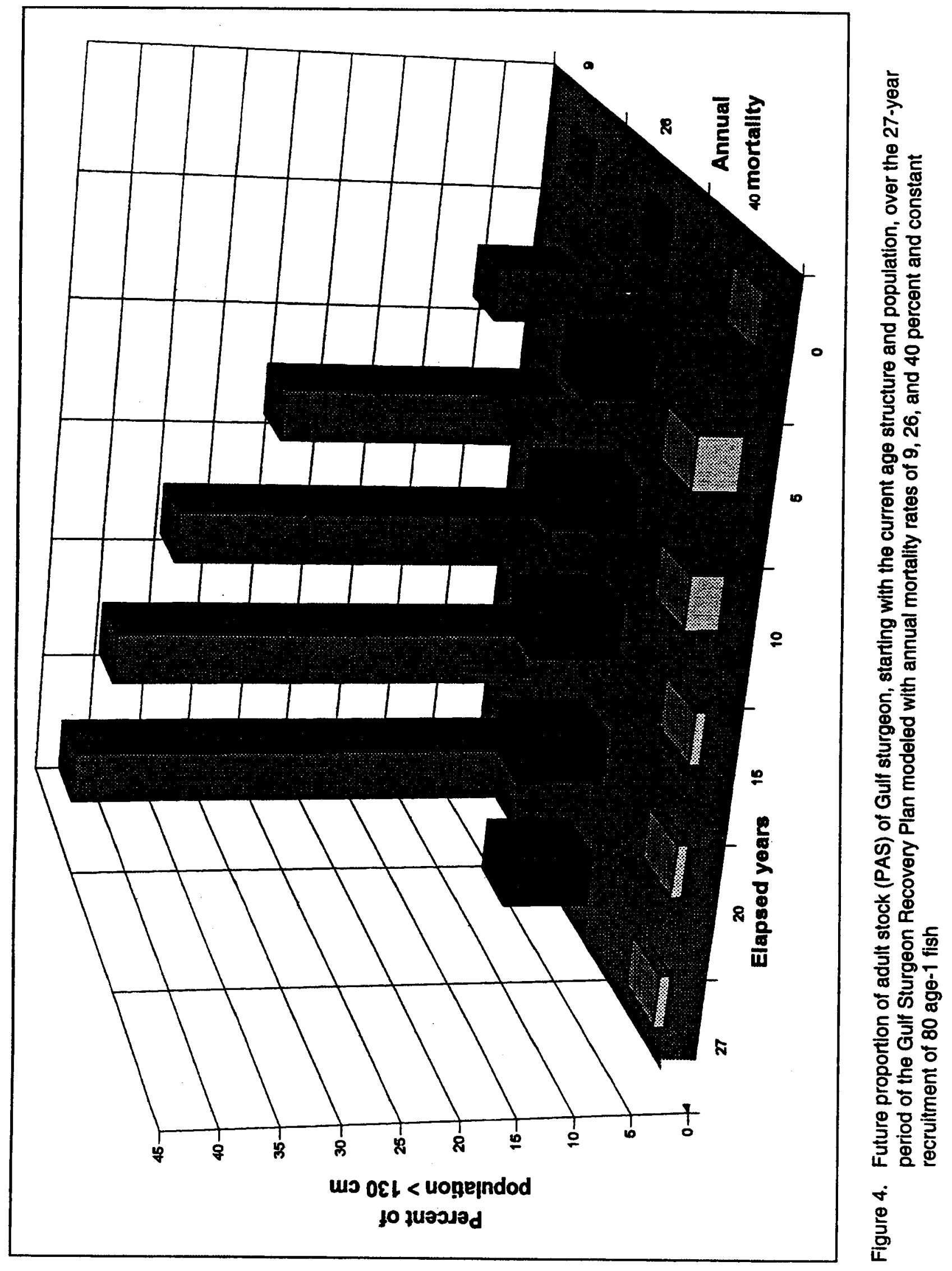




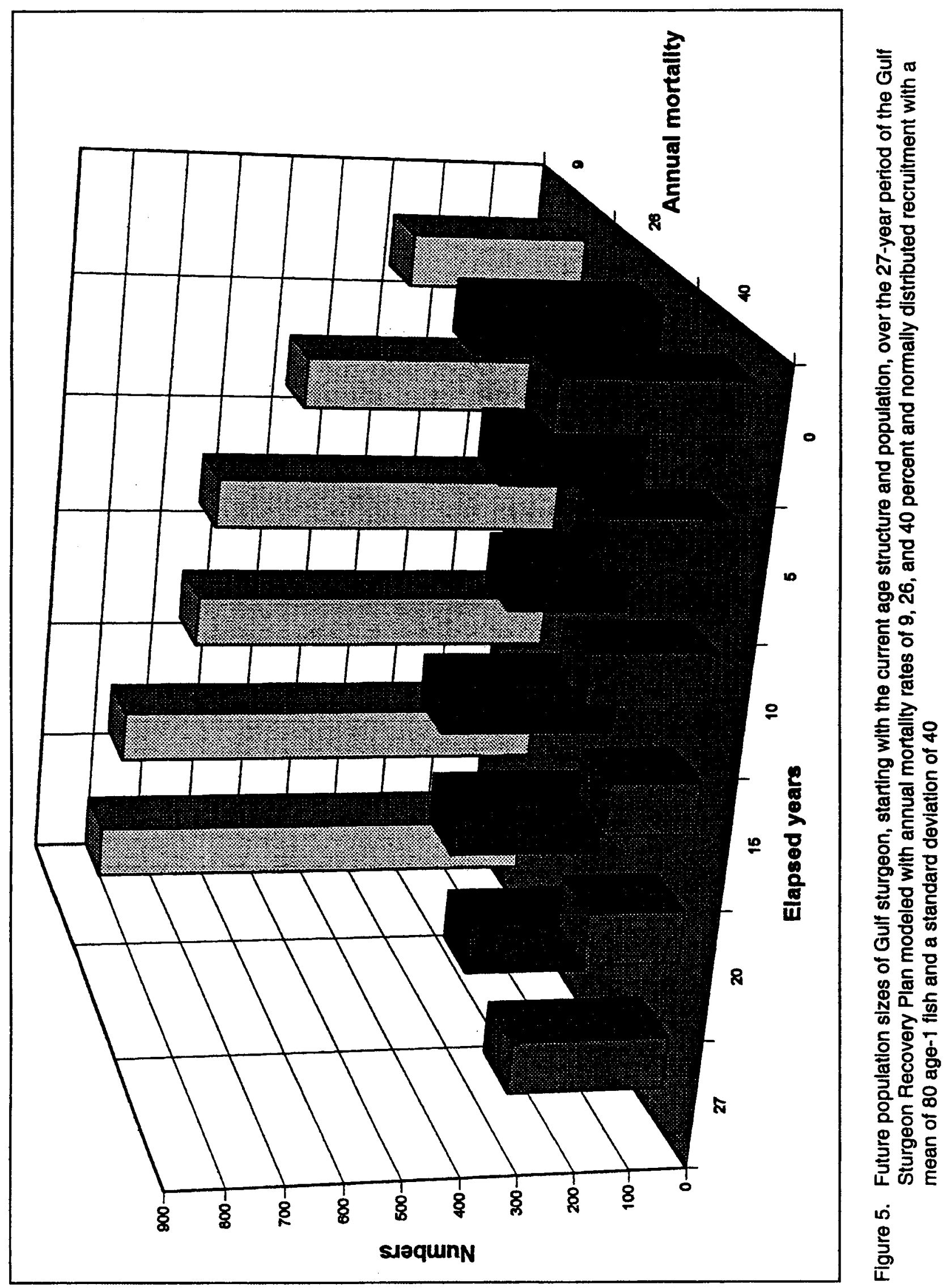




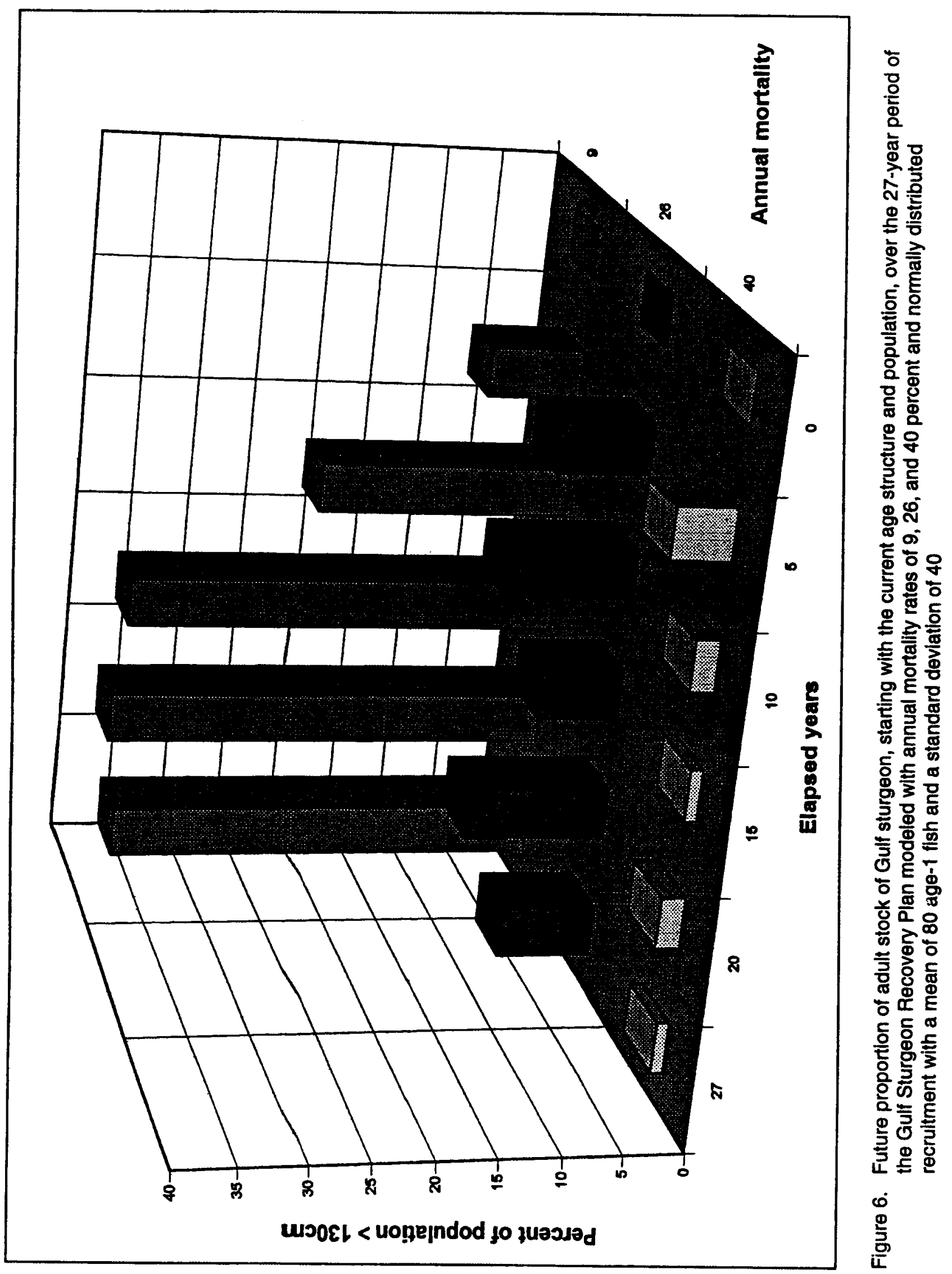


This study determined that number of recruits per adult necessary to maintain a self-sustaining population increases exponentially as mortality increases (Figure 7 ). As number of recruits per adult increases, PAS decreases, notwithstanding the mortality rate.

\section{Discussion}

Better population modeling will require a much improved understanding of recruitment, a daunting task with a threatened species. For the purpose of analysis, this study proposes two recovery trajectories based on extreme recruitment scenarios, namely scenarios 1 and 3 discussed in the previous section. The first scenario assumes that the spawning habitat is limiting at current population levels and recruitment will remain constant at approximately 80 age-1 fish per year. The second scenario assumes that the spawning habitat is not limiting at present population size, and approximately 10 age-1 recruits will be produced for each spawning-aged adult.

Under the first scenario, this study proposes that the population should double by 2023 in order for it to be considered safe from extirpation. The maximum mortality rate for this increase is 13 percent, which would result in a PAS of 25 percent, thus increasing the number of adult-sized fish by a factor of 17 over 1996 levels. Tag and recapture studies should be able to detect an increase in population size within 12 years after the target mortality rate is attained. A change in PAS may also be detectable within 4 to 5 years of reaching the target mortality rate.

Under the second scenario, this study proposes a maximum annual mortality rate of 18 percent, that will result in the population doubling in 12 years. An increase in population should be detectable within 5 to 6 years; however, PAS will not increase above 8 percent and may not be detectable over current levels until spawning habitats become limiting.

Based on samples from the West Middle River, population size has been at least stable since 1992 and age- 2 fish have been captured yearly (Morrow et al., in press). This may imply that these estimates of recruitment and number of recruits per adult may be conservative. Consequently, a very small number of adults may be maintaining the population (Rieman and Beamesderfer 1990). Thus, the population may be in a very precarious position, relying on few reproductive individuals, but it should respond favorably to reduced mortality rates. Sampling of this system should be continued with gill nets of mesh sizes ranging from $20-\mathrm{mm}$ to at least $90-\mathrm{mm}$ square mesh to insure that all size classes are fully vulnerable to capture. Improvements in the population, either in the form of improved PAS, larger population size, or both should be detectable with yearly summertime samples of 50 to 100 sturgeon from the West Middle River. If improvements are not detectable within ten years of implementing a recovery plan, then it must be assumed that mortality rate has not been reduced sufficiently. Any apparent decrease in Gulf sturgeon numbers, or any decrease in numbers of age- 2 sized fish should suggest a serious population decline. At the 


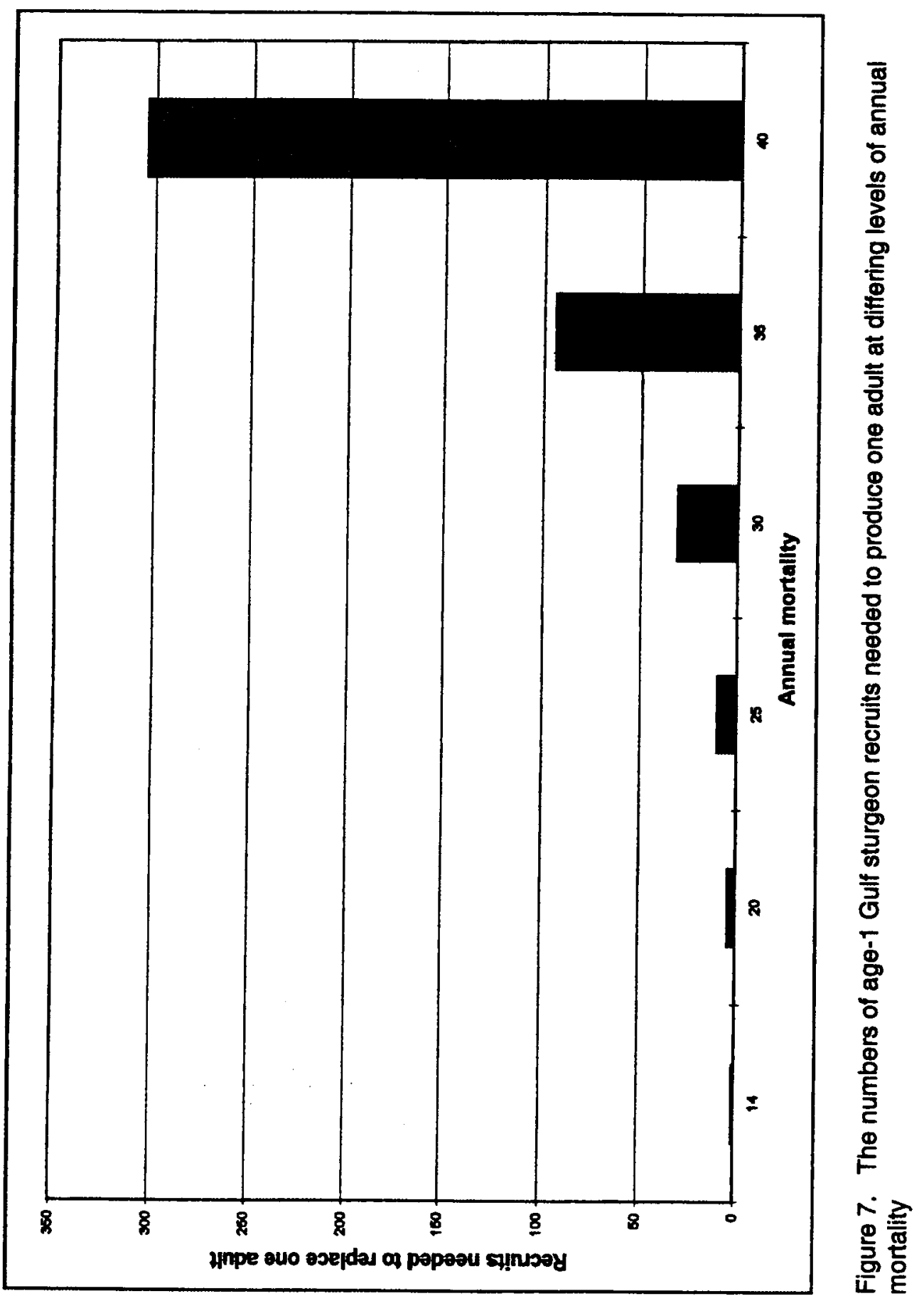


present 26 percent annual mortality rate and constant recruitment, the Pearl River Gulf sturgeon population is probably declining (Figures 3 and 4). Extirpation of this population could occur if adults become scarce enough that recruitment declines. A reduction in mortality to 19 to 23 percent will be necessary for the population to stabilize. Even with such a reduction, the population would still be in a very precarious position relying on very few reproductive adults. The results of modeling using normally distributed recruitment functions did not substantially alter these results (Figures 5 and 6).

\section{Enhancements to the Gulf Sturgeon Recovery Plan Using Population Modeling}

Fishery independent CPUE data often fails to detect population declines because of inherent variability in abundance estimates. Therefore, recovery based upon CPUE may be a tenuous criterion. Coefficients of variation (CVs) associated with estimated CPUE (gathered during 1992 through 1996) were generally greater than 200 percent despite a total sampling effort of 388,460 netmeter hours during the period of the study (Table 4). This variability suggests that such data are not robust enough to detect declining populations or that the sampling effort must be considerably higher.

\begin{tabular}{|c|c|c|c|}
\hline \multicolumn{4}{|c|}{$\begin{array}{l}\text { Table } 4 \\
\text { Mean Catch Per Unit Effort (CPUE) of Gulf Sturgeon Populations in } \\
\text { the Lower Pearl River, Mississippi-Louisiana Between } 1992 \text { and } \\
1996\end{array}$} \\
\hline Year & Sample size & CPUE & CV, percent \\
\hline 1992 & 31 & 0.0034 & 199 \\
\hline 1993 & 91 & 0.0021 & 212 \\
\hline 1994 & 80 & 0.0059 & 198 \\
\hline 1995 & 78 & 0.0085 & 237 \\
\hline 1996 & 127 & 0.0079 & 237 \\
\hline
\end{tabular}

A more serious problem with this approach is that populations with a constant CPUE could actually be declining. Figures 8 and 9 illustrate the response of the Pearl River population both in relative number and size structure over a wide range of mortality rates. For example, at annual mortality rates approximating 20 percent, the population remains relatively constant or begins to decline, eventually becoming dependent upon very few reproductive individuals. Catch per unit effort estimates would not detect the precarious nature of the population, and consecutive spawning failures could cause extirpation. The population described in Chapter 2 exemplifies this problem; annual mortality approached 25 percent and adults constituted about 1 to 3 percent of the total. The tenuous 


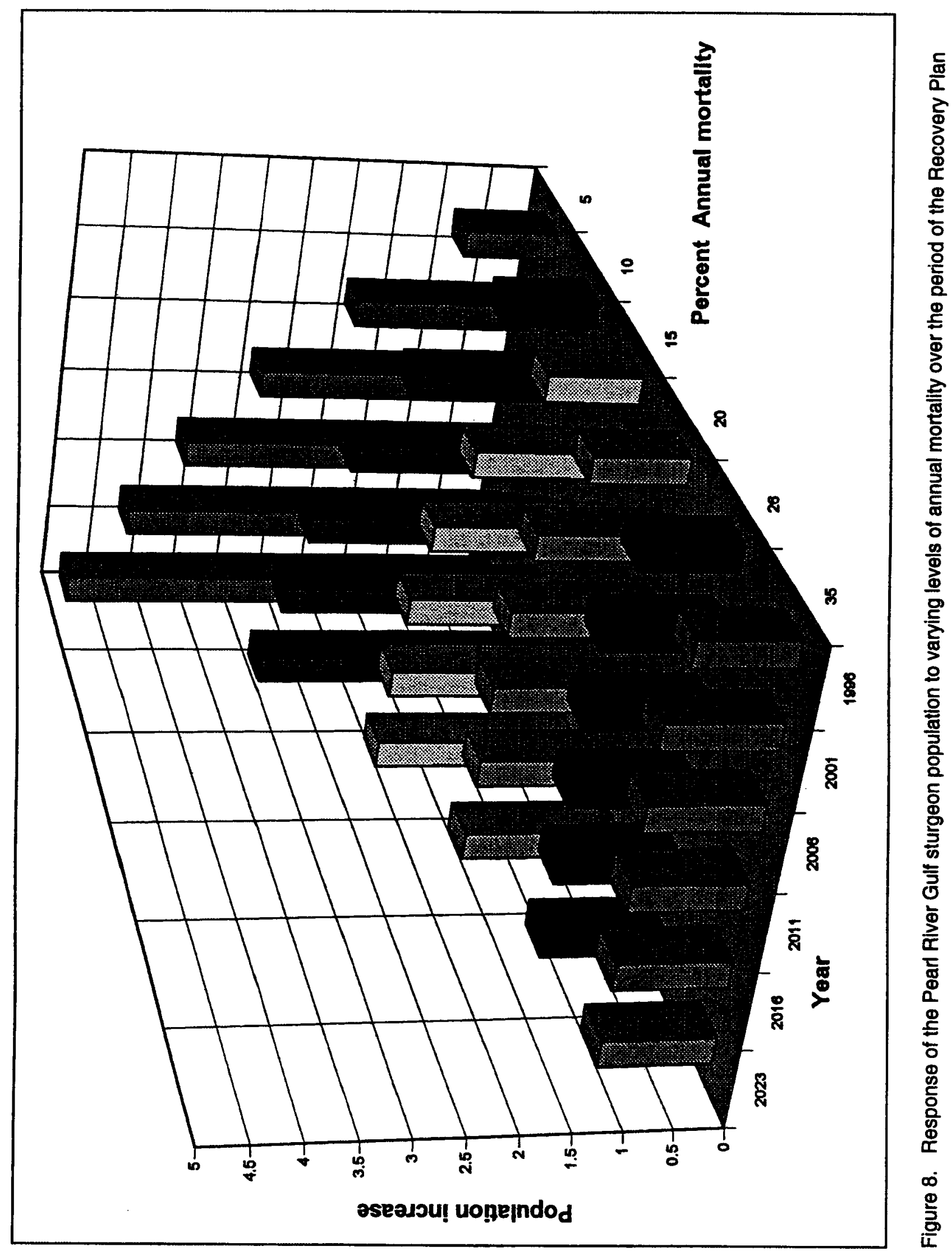




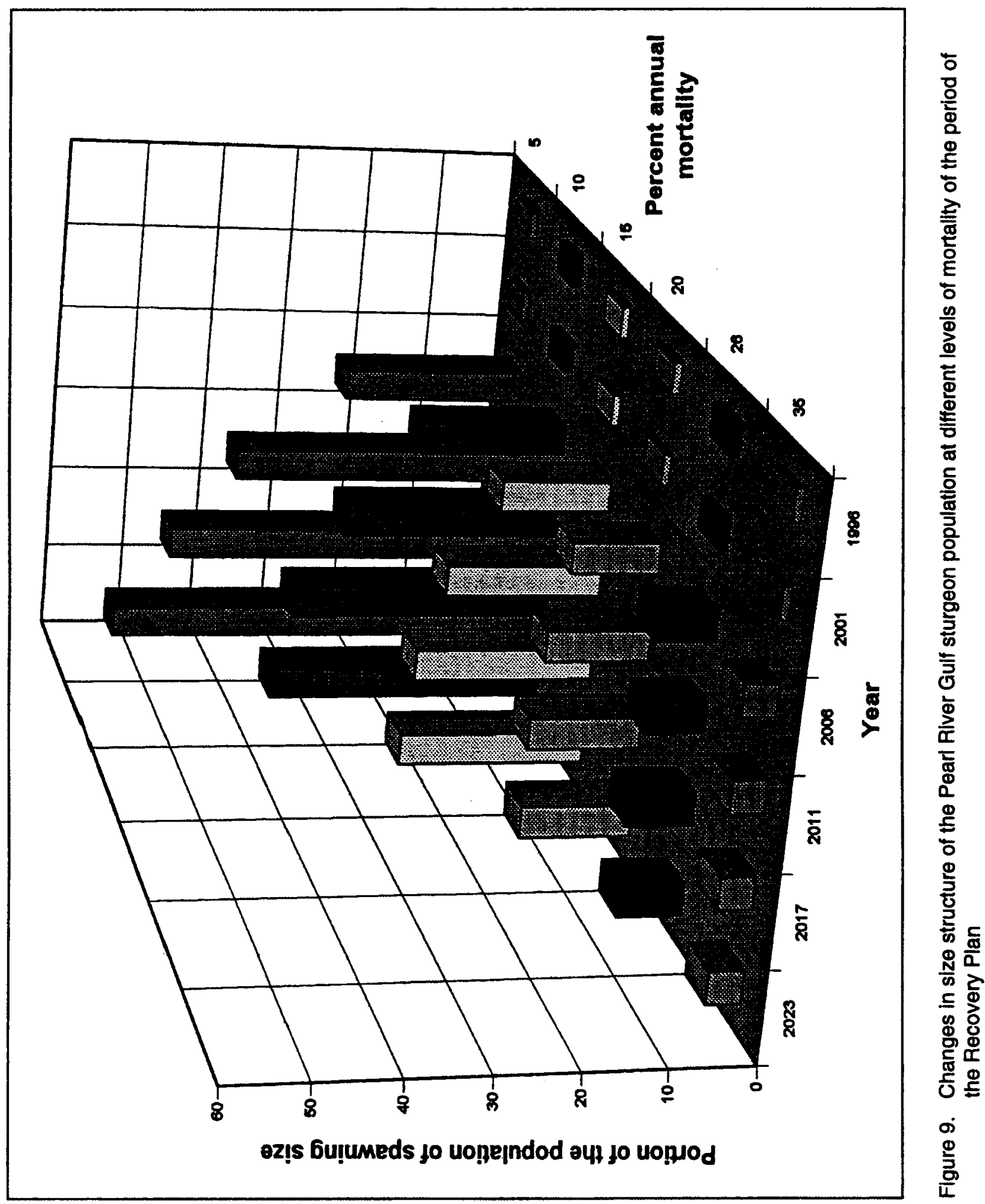

Chapter 3 Recommended Enhancements to the Gulf Sturgeon Recovery Plan 
status and poor recovery potential of this population would not be detected by relying only upon CPUE.

The long-term objective of the Recovery Plan is a self-sustaining population defined as having average recruitment equal to average mortality over a 12-year period. This study modeled the Pearl River population using the assumptions of the Recovery Plan; a self-sustaining population could sustain mortality rates of 25 percent and 40 percent using the most conservative and optimistic recruitment scenarios, respectively. These mortality rates are too high for even healthy sturgeon populations to sustain for an extended period (Rieman and Beamesderfer 1990); modeling suggests the population would decline to very low numbers sustained by a few adults (Figures 8 and 9). Therefore, it is recommended that the minimum population size and the number of reproductive individuals be defined for a self-sustaining population. In the case of the Pearl River system, a PAS of 8 to approximately 25 percent based upon the assumptions of the stock-recruitment function and a doubling of the current population size to about 600 individuals is recommended.

The long-term objective also relies on defining recruitment, a parameter that is difficult to estimate for sturgeons. Developing a recruitment function suitable for population modeling will require accurate estimates of age- 1 fish and the number of potential spawning adults for consecutive years. Estimation of recruitment represents a shortcoming for both the Recovery Plan and the population modeling. This problem was approached by using a variety of recruitment functions that included the most optimistic and pessimistic extremes.

The Recovery Plan does not rely on quantitative estimates of population size and dynamics but rather on relative estimates of abundance, i. e., CPUE. CPUE data may not reveal low populations sizes (Schnute and Richards 1995) or unsatisfactory age structure. As illustrated, CPUE information can lead to spurious results that may actually contribute to the extirpation of populations. Modeling also provides insight into recovery trajectories (Powers 1996) that consider sources of mortality (such as commercial by-catch), a suitable age and size structure, and the effects of errors in parameter estimation.

Most sturgeons have declined drastically due to over-exploitation and habitat destruction (Birstein 1993). Because of slow growth, long periods of sexual immaturity, and differential spawning chronologies of males and females, setting population goals in recovery plans is difficult. However, modeling does not require considerably more effort than traditional assessments of population status and can aid in developing recovery strategies. Once a river system is adequately surveyed, most agencies can identify areas of concentration and develop age, growth and mortality relationships. New retail modeling software allows various scenarios of recruitment and mortality to be evaluated simultaneously, so management options can be quantitatively determined. 


\section{Conclusions and Recommendations}

Conclusions of this study are as follows:

a. The Pearl River Gulf sturgeon population is estimated at about 300 individuals with adults comprising 1 to 3 percent of the population.

b. Over the last 30 years, annual mortality rates ranged from 9 to almost 40 percent and were significantly correlated with commercial fishing effort. From 1992 to 1996, average annual mortality was estimated at approximately 26 percent.

Recommendations based on study results are as follows:

a. Restoration efforts should focus on reducing annual mortality rates and improving habitat.

b. Population modeling is recommended as a tool to enhance the Recovery Program by utilizing population and recruitment estimates, size structure, and mortality rates. Such quantitative approaches represent an improvement on measures of catch per effort and recruitment. Based upon modeling results, for the Pearl River population to recover the average annual mortality rates would need to fall into the range of 13 to 18 percent and the population should at least double.

c. Future targets in the Recovery Plan should focus on an acceptable population size and age structure for a given river system. To use population modeling, the population size and age structure should be estimated, mortality and recruitment rates developed, and an acceptable recovery trajectory formulated. 


\section{References}

Barkuloo, J. M. (1988). "Report on the conservation status of the Gulf of Mexico Sturgeon, Acipenser oxyrhynchus desotoi," U. S. Fish and Wildlife Service, Panama City, FL.

Beamesderfer, R. C. P. (1991). "MOCPOP 2.0: A flexible system for simulation of age-structured populations and stock-related functions," Information Report 91-4, Oregon Department of Fish and Wildlife, Portland.

Beamesderfer, R. C. P., and Farr, R. A. (1997). "Alternatives for the protection and restoration of sturgeons and their habitat," Evolutionary Biology of Fishes $48,407-17$.

Birstein, V. J. (1993). "Sturgeons and paddlefishes; fishes in need of conservation," Conservation Biology 7(4), 773-87.

Carr, A. (1983). "All the way down upon the Suwannee River," Audubon 3, 80-101.

Clugston, J. P., Foster, A. M., and Carr, S. H. (1995). "Gulf sturgeon, Acipenser oxyrinchus desotoi, in the Suwannee River, Florida, USA." International Symposium on Sturgeons Proceedings. Moscow, Russia. A. D. Gershanovich and T. I. J. Smith, ed. 215-24.

Collins, M. R., Rogers, S. G., and Smith, T. I. J. (1996). "Bycatch of sturgeons along the southern Atlantic coast of the USA," North American Journal of Fisheries Management 16, 24-9.

Davis, J. T., Fontenot, B. J., Hoenke, C. E., Williams, A. M., and Hughes, J. S. (1970). "Ecological factors affecting anadromous fishes of Lake Pontchartrain and its tributaries," Fisheries Bulletin Number 9, Louisiana Wildlife and Fisheries Commission.

Everhart, W. H., Eipper, A., and Youngs, W. D. (1975). Principles of Fishery Science. Comell University Press. 
Foster, A. M. (1993). "Movement of Gulf sturgeon, Acipenser oxyrinchus desotoi, in the Suwannee River, Florida," M.S. thesis, University of Florida, Gainesville.

Gulland, J. A. (1983). "Fish stock assessment, a manual of basic methods." FAO/Wiley series on food and agriculture, Volume 1. Wiley, New York.

Huff, J. A. (1975). "Life history of Gulf of Mexico sturgeon, Acipenser oxyrhynchus desotoi, in Suwannee River, Florida," Florida Marine Research Publications, Number 16, Florida Department of Natural Resources.

Knight, C. L. (in press). "Gulf sturgeon migration patterns and habitat selection in the Pearl River system," Project No. E-1, Segment 10, Mississippi Department of Wildlife, Fisheries, and Parks.

Lee, D. S., Gilbert, C. R., Hocutt, C. H., Jenkins, R. E., McAllister, D. E., and Stauffer, J. R. (1980). "Atlas of North American freshwater fishes," Publication \#1980-12, North Carolina Biological Survey.

Marchant, S. R., and Shutters, M. K. (1996). "Artificial substrates collect Gulf sturgeon eggs," North American Journal of Fisheries Management 16, 445-47.

Miranda, L. E., and Jackson, D. C. (1987). "A status survey of Atlantic sturgeon in the Pascagoula and the Pearl River systems of Mississippi," Museum of Natural Science Technical Report Number 2, Mississippi Department of Wildlife and Fisheries and Parks.

Morrow, J. V., Jr., Killgore, K. J., Kirk, J. P., and Rogillio, H. E. (in press). "Distribution and population attributes of Gulf sturgeon in the lower Pearl River system, Louisiana." Proceedings of the 50th Annual Conference of the Southeastern Association of Fish and Wildlife Agencies, Hot Springs, Arkansas, 5-9 October 1996.

Odenkirk, J. S. (1989). "Movements of Gulf of Mexico sturgeon in the Apalachicola River, Florida." Proceedings of the Annual Conference of the Southeastern Association of Fish and Wildlife Agencies 43, 230-38.

Powers, J. E. (1996). "Benchmark requirements for recovering fish stocks," North American Journal of Fisheries Management 16, 495-504.

Rieman, B. E., and Beamesderfer, R. C. (1990). "White sturgeon in the lower Columbia River: Is the stock overexploited?" North American Journal of Fisheries Management 10, 388-96.

Rien, T. A., and Beamesderfer, R. C. (1994). "Accuracy and precision of white sturgeon age estimates from pectoral fin rays." Transactions of the American Fisheries Society. 123, 255-65. 
Ricker, W. E. (1975). "Computation and interpretation of biological statistics of fish populations," Bulletin 191, Bulletin of the Fisheries Research Board of Canada.

Schnabel, Z. E. (1938). "The estimation of total fish populations in a lake," American Mathematical Monograph 45(6), 348-52.

Schnute, J. T., and Richards, L. J. (1995). "The influence of error on population estimates from catch-age models," Canadian Journal of Fisheries and Aquatic Science 52, 2063-77.

Stone, J. H., Bahr, L. M., Jr., Day, J. W., and Darnell, R. M. (1980). "Ecological effects of urbanization on Lake Pontchartrain, Louisiana, between 1953 and 1978 with implications for management." Proceedings of the 1980 Conference on Urban Ecology, Berlin, Germany. R. Bornkamm, J. A. Lee, and M. R. D. Seward, ed., 243-52.

U. S. Army Engineer District, Mobile. (1970). "Pearl River Comprehensive Basin Study, Volume 1, Main report," Mobile, AL.

U. S. Fish and Wildlife Service. (1991). "Endangered and threatened wildlife and plants: threatened status for the Gulf sturgeon." Federal Register 56, 49653-58.

U. S. Fish and Wildlife Service and Gulf States Marine Fisheries Commission. (1995). Gulf Sturgeon Recovery / Management Plan. Atlanta, GA.

Vladykov, V. D. (1955). "A comparison of the Atlantic sea sturgeon with a new subspecies of the Gulf of Mexico (Acipenser oxyrhynchus desotoi)," Journal of the Fisheries Research Board of Canada 12, 754-61.

Wooley, C. M., Moon, P. A., and Crateau, E. J. (1982). "A larval Gulf of Mexico sturgeon (Acipenser oxyrhynchus desotoi) from the Apalachicola River, Florida," Northeast Gulf Science 5, 57-8.

Wooley, C. M., and Crateau, E. J. (1985). "Movement, microhabitat, exploitation, and management of Gulf of Mexico sturgeon, Apalachicola River, Florida," North American Journal of Fisheries Management 5 , 590-605. 


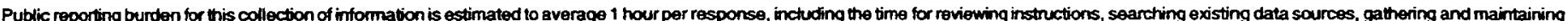

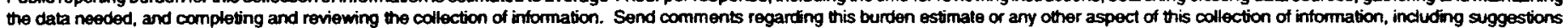

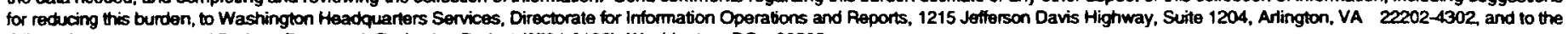
Office of Management and Budget, Papenwork Reduction Project (0704-0188), Wastington, DC 20503.
1. AGENCY USE ONLY (Leave blank)
2. REPORT DATE
3. REPORT TYPE AND DATES COVERED
April 1998
Final report

4. TITLE AND SUBTTTLE

Use of Population Modeling to Enhance the Gulf Sturgeon Recovery Plan

5. FUNDING NUMBERS

6. AUTHOR(S)

James P. Kirk, K. Jack Killgore, James V. Morrow, Jr., Howard E. Rogillio, Charles Knight

7. PERFORMING ORGANIZATION NAME(S) AND ADDRESS(ES)

U.S. Army Engineer Waterways Experiment Station, 3909 Halls Ferry Road,

Vicksburg, MS 39180-6199; Louisiana Department of Wildlife and Fisheries,

8. PERFORMING ORGANIZATION REPORT NUMBER

61386 Fish Hatchery Road, LaCombe, LA 70445; Mississippi Museum of Natural Sciences, 111 North Jefferson Street, Jackson, MS 39202

9. SPONSORING/MONITORING AGENCY NAME(S) AND ADDRESS(ES)

U.S. Army Corps of Engineers

Technical Report EL-98-3

Washington, DC 20314-1000

10. SPONSORINGMONTORING AGENCY REPORT NUMBER

\section{SUPPLEMENTARY NOTES}

Available from National Technical Information Service, 5285 Port Royal Road, Springfield, VA 22161.

12a. DISTRIBUTIONAVAILABILITY STATEMENT

Approved for public release; distribution is unlimited.

12b. DISTRIBUTION CODE

13. ABSTRACT (Maximum 200 words)

The Gulf sturgeon population in the Pearl River was monitored from 1992 through 1996 and compared to historical data sets from the 1960 s and 1980 s. The estimated population size in 1996 was approximately 300 fish with adults comprising about 3 percent of the population. Annual mortality rates in the late 1960s were about 9 percent; these rates increased to almost 40 percent in 1985 and decreased to about 26 percent during 1992 through 1996. Population modeling was used to evaluate the sturgeon's status and recovery potential. Results of models suggest that this population can only withstand mortality rates in the range of 13 to 18 percent, depending upon recruitment assumptions. Population models indicated that catch and fishing effort data specified in the Gulf Sturgeon Recovery Plan may not detect a declining population. Population models can be used to simulate annual variation in population size under different rates of mortality. Recovery goals can address a specific source of mortality simulated in the model, and monitoring can determine the success of recovery efforts. Population modeling does not require considerably more effort or expertise over that already required to conduct monitoring studies.

14. SUBJECT TERMS

Gulf sturgeon

Mortality
Population modeling

Recovery plan
15. MUMBER OF PAGES

32

16. PRICE CODE

\begin{tabular}{|c|c|c|c|c|}
\hline 17. & $\begin{array}{l}\text { SECURITY CLASSIFICATION } \\
\text { OF REPORT }\end{array}$ & 18. & $\begin{array}{l}\text { SECURIY CLASSIFICATION } \\
\text { OF THIS PAGE }\end{array}$ & $\begin{array}{l}\text { 19. SECUAITY CLASSIFICATION } \\
\text { OF ABSTRACT }\end{array}$ \\
\hline & UNCLASSIFIED & & UNCLASSIFIED & \\
\hline
\end{tabular}

NSN 7540-01-280-5500
Standard Form 298 (Rev. 2-89) Prescribed by ANSI STd. Z39-18 298-102 
Destroy this report when no longer needed. Do not return it to the originator. 